\title{
Penentuan Jenis Baja Scrap sebagai Bahan Baku Proses Pengecoran Logam di IKM dengan Metode Spark Testing
}

\author{
Muhamad Sukis ${ }^{*}$, Rusnaldy ${ }^{2}$, Paryanto ${ }^{3}$, Natalino Fonseca D.S. Guterres ${ }^{4}$ \\ ${ }^{1,3}$ Departemen Teknik Mesin, Universitas Diponegoro \\ J1. Prof. Sudarto No.13, Tembalang, Kec. Tembalang, Kota Semarang, Jawa Tengah 50275 \\ ${ }^{2,4}$ Departemen Teknik Mesin, Dili Institute of Technology \\ Street Aimeti - Laran Aimutin, Dili-Timor Leste \\ *E-mail: muh.sukis.13@gmail.com
}

Diterima: 15-02-2021; Direvisi: 18-07-2021; Dipublikasi: 25-08-2021

\begin{abstract}
Abstrak
Pengecoran logam di Indonesia sangat diperlukan di industri manufaktur, salah satu faktor yang sering terjadi adalah proses pemilihan material awal pada pengecoran, terutama mengetahuai unsur yang terkandung didalam baja scrap. Salah satu metode untuk mengetahui kandungan karbon pada baja scrap adalah metode spark testing. Penelitian ini bertujuan untuk menganalisis karakterisasi spark pada proses gerinda melalui identifikasi jenis baja scrap berdasarkan panjang spark, sudut spark dan sudut kontak spark. Dimensi dari sampel meliputi 100x50x10 mm, sudut pemakanan adalah $75^{\circ}$ dengan grit size batu gerinda yaitu 36, 60 dan 80. Penekanan menggunakan gaya gravitasi dari spesimen itu sendiri selama 30 detik. Perbedaan volume stream dan bentuk karakterisasi spark dipengaruhi oleh kandungan komposisi kimia baja dan grit batu gerinda. Dengan menggunakan metode ini dapat mempermudah identifikasi awal baja scrap sebelum dilakukan pengecoran logam, sehingga hasil yang didapat adalah material dengan kandungan karbon lebih tinggi menghasilkan sudut spark melebar, kemudian sudut kontak akan mengecil dan ukuran spark semakin pendek. Kandungan karbon $0,54 \% \mathrm{C}$ telah menghasilkan pancaran burst lebih banyak. Menggunakan ukuran batu gerinda 80 grit (fine) telah menghasilkan jarak pada pancaran burts terjadi melebar di semua material.
\end{abstract}

Kata kunci: identifikasi material; material; spark testing

\begin{abstract}
Metal casting in Indonesia is very essential in the manufacturing industry, one of the factors that often occurs is the initial material selection in the metal foundry, especially in determining the elements contained in scrap steel. One method to determine the carbon content of scrap steel is the spark testing method. This study aims to analyze the characterization of the spark in the grinding process by identifying the type of scrap steel based on the length of the spark, the spark angle, and the spark contact angle. The dimensions of the sample include 100x50x10 mm, the feeding angle is $75^{\circ}$ with a grit size grinding wheel of 36, 60, and 80. Emphasis is applied using gravity from the specimen itself for 30 seconds. The difference in stream volume and shape of the spark characterization is influenced by the chemical composition of the steel and the grit of the grinding wheel. Using this method can facilitate the initial identification of scrap steel before metal casting is carried out so that the results obtained are materials with a higher carbon content resulting in a wider spark angle, then the contact angle will decrease and the spark size will be shorter. The carbon content of 0.54\% C has resulted in more burst emissions. Using a grinding wheel size of 80 grit (fine) has resulted in a wide beam distance of burst in all materials.
\end{abstract}

Keywords: material identification; material; spark testing

\section{Pendahuluan}

Perkembangan industri logam di Indonesia terus tumbuh terutama pengecoran logam yang terletak di Klaten Jawa Tengah yang memproduksi berbagai macam produk cor. Bahan dasar pengecoran logam adalah baja scrap, pemilihan baja scrap di awal sangatlah penting sebelum dilakukan proses pengecoran. Cara membedakan baja scrap sebagai bahan dasar awal pengecoran di IKM para operator menggunakan pengamatan visual dengan cara ditekuk. Kekurangan dari metode yang dilakukan adalah belum bisa secara signifikan membedakan baja karbon scrap di awal sebelum di lakukan peleburan. Pengukuran menggunakan metode fractal box berdasarkan pengamatan percikan dan pemrosesan gambar menunjukkan korelasi yang baik antara dimensi fraktal dan kadar karbon baja dan kesalahan pengukuran kandungan karbon adalah 0,06\% 
[1]. Penggunan kamera thermal untuk membaca tanda panas setelah spark test dilakukan pada ubin quari untuk membedakan kandungan karbon. Bahwa material yang berbeda memiliki sifat termo-fisik yang berbeda, masing-masing harus menghasilkan tanda tangan termal yang berbeda untuk mengidentifikasi sampel yang tidak diketahui secara positif, seseorang harus mengeksploitasi beberapa sifat material lain dengan menggunakan beberapa pengujian sederhana, seperti massa jenis, kekerasan, sifat magnet, panjang percikan dan sudut ekstrim dari percikan api [2].

Metode spark test telah banyak digunakan diberbagai bidang Industri skala pabrik ataupun Industri Kecil Menengah. Spark test dipakai pengrajin pandai besi tradisional untuk membedakan kandungan karbon. Sehingga pengrajin menghasilkan produk pertanian dan rumah tangga dengan kualitas dan mutu yang bagus sehingga dapat bersaing dengan industry di luar negeri [3]. Banyaknya kandungan karbon pada material berpengaruh terhadap panjang spark yang dihasilkan pendek dan sudutnya lebar semakin sedikitnya kandungan karbon sudut spark semakin kecil dan panjang spark bertambah panjang [4]. Semakin keras material baja maka semakin ringan geram yang dihasilkan dan semakin keras material maka panjang spark semakin pendek dan sudutnya semakin lebar [5]. Komposisi yang terkandung pada baja mempengaruhi karakteristik spark pada gerinda, semakin tinggi kadar karbon bentuk spark stars bursts dan fork bursts lebih jelas. Semakin tinggi komposisi paduan $\mathrm{Cr}$ menghasilkan spark flowers bursts lebih jelas dan berwarna kuning tua. alloy steel dengan nikel menghasilkan spark flower dan starsts bursts [6]. Intensitas warna dan pola spark test sangat berpengaruh terhadap unsur yang terkandung didalam material tersebut setelah dilakukan pengujian dengan menggunakan alat rapid-scanning spectrometer system [7].

Hubungan antara struktur mikro baja dan pemisahan antara spark menggunakan dua material baja yang berbeda yaitu hipoeutektoid (mengandung kurang dari 0,8\% karbon) dan hipereutektoid (> 0,8\% karbon). Menggunakan kamera berkecepatan tinggi $1000 \mathrm{fps}$ untuk mengamati spark api dengan pemindaian menggunakan alat Mikroskop Elektron menggambarkan mikrostruktur yaitu sebelum terjadi proses ledakan dan membentuk spark $\mathrm{CO}^{2}$ beroksidasi dengan $\mathrm{Fe} 3 \mathrm{C}$ kemudian menghasilkan tekanan internal [8]. Variasi spark dibagi dalam tiga sektor dimulai dari pangkal adalah sektor pertama, bagian tengah merupakan sektor kedua, dan bagian ujung spark merupakan sektor ketiga dan spark terbentuk didalam partikel bola terlepas melalui permukaan rapuh dan memunculkan "series spark bursts" [9]. Mengembangkan teknik pengujian percikan otomatis untuk mengukur kandungan karbon dalam bahan baja berdasarkan pemrosesan gambar. Dengan menggunakan material kandungan karbon $0,1 \%-0,44 \%$, teknik ini mendeteksi percikan ledakan dan percikan api streamline disemua gambar yang diambil dan menghitung rasio percikan ledakan yang didefinisikan sebagai jumlah spark ledakan dibagi dengan jumlah semua percikan [10]. Tidak semua paduan menghasilkan spark pada saat di gerinda [11]. Sifat fisik kimia pada material berguna untuk evaluasi awal pembentukan percikan dan lapisan bubuk energi pengapian dari lapisan debu dapat menjadi indikator untuk mengevaluasi percikan [12]. Baja karbon rendah umumnya memiliki poros jalur percikan api yang panjang, dengan sedikit semburan [13].

Metode observasi percikan hanya cocok untuk pekerja berpengalaman. Untuk mengatasi batasan tersebut, pengenalan komputer diadopsi untuk mengidentifikasi gambar percikan yang ditangkap dengan ponsel atau kamera, yang membuat batasan lebih kecil dan meningkatkan efisiensi pengujian percikan. Pengenalan komputer memiliki perkembangan kecepatan tinggi dan aplikasi yang tersebar luas di bidang pengenalan, seperti pengenalan sidik jari dan pengenalan wajah [14]. Kelebihan dari spark test yaitu bisa secara cepat mengidentifikasi jenis material baja karbon. Dengan menggunakan metode ini dapat mempermudah identifikasi awal baja scrap sebelum dilakukan pengecoran logam. Penelitian ini bertujuan untuk menganalisis karakterisasi spark pada proses gerinda melalui identifikasi jenis baja scrap berdasarkan panjang spark, sudut spark dan sudut kontak spark. 
Muhamad Sukis dkk /Jurnal Rekayasa Mesin

p-ISSN: 1411-6863, e-ISSN: 2540-7678

Vol.16|No.2|157-164|Agustus|2021

\section{Metodologi Penelitian}

Penelitian dilakukan di Laboratorium proses produksi Universitas Muria Kudus Jawa Tengah. Penelitian diawali dengan pengukuran dimensi spesimen $100 \times 10 \times 50 \mathrm{~mm}$, yang terdiri dari baja scrap alat berat (BSA) dan baja scrap industri manufaktur (BSI). Alat yang digunakan gerinda merk Modern Bench Grinder MD - 150 enam inch, 250 watt, 2950 rpm. Variasi batu gerinda grit size 36, 60 dan 80 aluminium oxide sudut kontak $75^{\circ}$ gaya gravitasi digunakan untuk menghasilkan gaya konstan pada benda kerja. Lengan pencekam pada Gambar 1.a berguna menstabilkan benda kerja pada saat kontak dengan batu gerinda selama 30 detik. Citra diambil beberapa kali secara tegak lurus sesuai arah aliran percikan, papan belakang hitam untuk memberikan kontras yang jelas dan diberi skala mm. Pengambilan citra dengan jarak kurang lebih 1,5 meter dari titik obyek menggunakan kamera sony a 7 marc II seperti pada Gambar 1.b dan 1.c. Setelah dilakukan uji spark pada sampel, kemudian di uji spectrometri untuk mengetahui kandungan karbon dan unsur kimia yang terdapat di baja scrap pada Tabel 1.

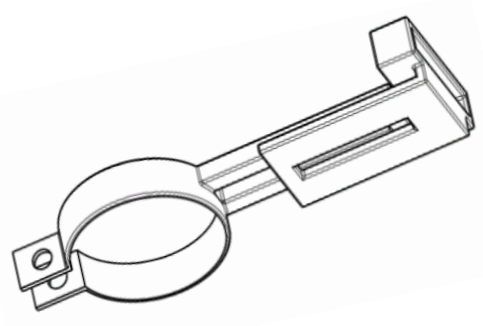

a.

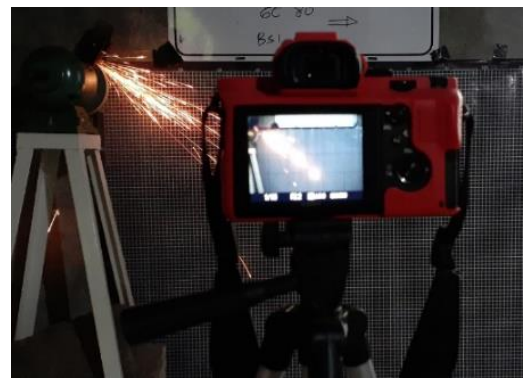

b.

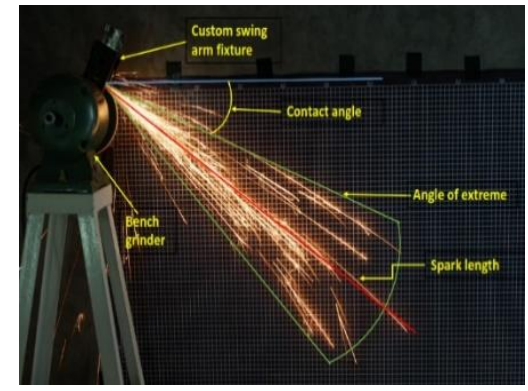

c.

Gambar 1. a. Lengan pencekam, b. Pengambilan citra, c. Pengambilan data

Pada penelitian ini menggunakan software ImageJ untuk mendapatkan pengukuran panjang spark, sudut spark dan sudut kontak spark. Skala mm digunakan bersamaan dengan perangkat lunak dan data dikumpulkan menggunakan perangkat lunak imageJ. Foto spark diunggah dengan menggunakan piksel referensi untuk mengukur panjang garis seperti pada Gambar 2. Skala ditentukan dengan menggambar garis dari jarak yang diketahui dalam hal ini $\mathrm{mm}$ dan mengatur jumlah piksel. Panjang dari percikan diukur dengan menarik garis mulai percikan dari roda gerinda sampai ujung percikan dengan perangkat lunak dan menyimpannya dalam tabel Excel.

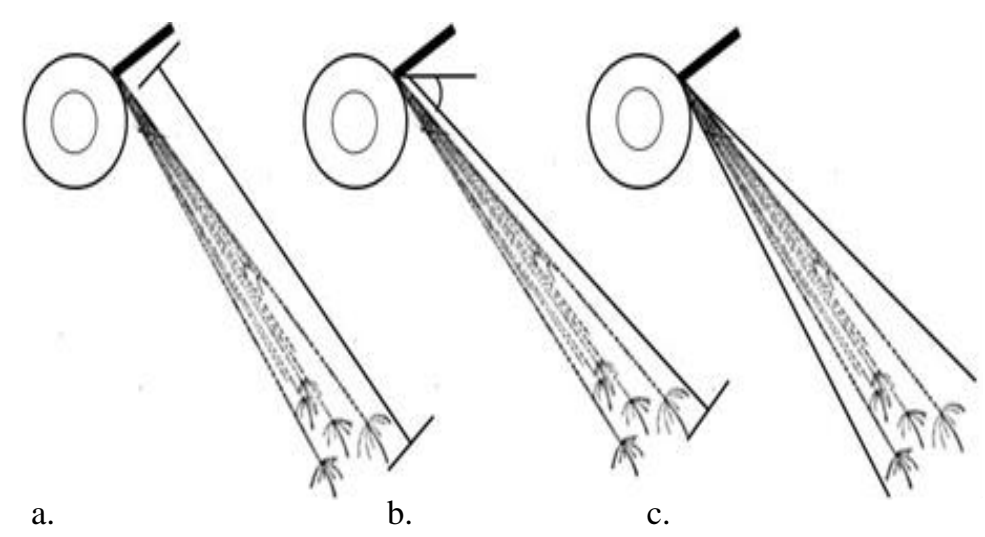

Gambar 2. a. Panjang spark, b. Sudut kontak spark, c. Sudut park 
Muhamad Sukis dkk /Jurnal Rekayasa Mesin

p-ISSN: 1411-6863, e-ISSN: 2540-7678

Vol.16|No.2|157-164|Agustus|2021

\subsection{Uji komposisi kimia}

Setelah dilakukan pengujian percikan pada baja karbon, kemudian dilakukan uji spectrometri untuk membandingkan antara karakterisasi percikan dengan kandungan karbon pada spesimen. Hasil uji komposisi menunjukan bahwa unsur yang paling dominan pada kedua jenis material baja scrap ini adalah unsur Fe rata - rata 97,1\% bisa dilihat pada Tabel 4 . Nilai karbon $\mathrm{C}$ adalah rata - rata di bawah 30\% sehingga termasuk baja karbon rendah kecuali BSA 02 dengan kadar C 0,54\% sehingga termasuk baja karbon menengah dan sisanya adalah unsur paduan. Selain itu, untuk baja scrap BSA 01 unsur paduan $\mathrm{Mn}$ dan $\mathrm{Cr}$ di atas $1 \%$ pada baja paduan menambah kekuatan, meningkatkan keuletan, kekerasan, ketahanan aus, dan ketahanan panas seperti proses pembuatan bucket tooth excavator [15]. Unsur - unsur paduan yang terdapat pada spesimen tersebut yaitu Si, Mn, P, S, Cr, Mo, Cu. Unsur paduan selain C pada baja karbon rendah ini total kurang dari 5\%, sehingga baja ini digolongkan baja paduan rendah

Tabel 1. Pengujian komposisi baja scrap alat berat dan baja scrap industri

\begin{tabular}{cccccccccc}
\hline Spesimen & \multicolumn{10}{c}{ Uji komposisi kimia (\%) } \\
\hline Baja scrap alat berat & $\mathrm{C}$ & $\mathrm{Mn}$ & $\mathrm{P}$ & $\mathrm{S}$ & $\mathrm{Cr}$ & $\mathrm{Si}$ & $\mathrm{Mo}$ & $\mathrm{Cu}$ & $\mathrm{Fe}$ \\
BSA 01 & 0,21 & 1,13 & 0,06 & 0,03 & 1,49 & 0,18 & 0,17 & 0,02 & 95,5 \\
BSA 02 & 0,54 & 0,69 & 0,04 & 0,02 & 0,72 & 0,28 & 0,02 & 0,02 & 97,4 \\
Baja scrap industri manufaktur & $\mathrm{C}$ & $\mathrm{Mn}$ & $\mathrm{P}$ & $\mathrm{S}$ & $\mathrm{Cr}$ & $\mathrm{Si}$ & $\mathrm{Mo}$ & $\mathrm{Cu}$ & $\mathrm{Fe}$ \\
BSI 01 & 0,17 & 0,62 & 0,04 & 0,02 & 0,01 & 0,24 & 0,01 & 0,01 & 98,6 \\
BSI 02 & 0,20 & 0,39 & 0,04 & 0,04 & 0,18 & 0,18 & 0,05 & 0,16 & 97,1 \\
\hline
\end{tabular}

\section{Hasil Penelitian Dan Pembahasan}

H. Rawani K [4] telah melakukan penelitian berbagai material baja karbon hasil yang didapatkan yaitu semakin tingginya kandungan karbon pada material maka panjang spark yang dihasilkan semakin pendek dan semakin lebar sudutnya, dan semakin sedikitnya kandungan karbon maka sudut spark semakin kecil dan panjang spark bertambah panjang. Batu gerinda pada tingkat kekasaran 36 grit menghasilkan spark sangat panjang yaitu $1.171 \mathrm{~mm}$ pada material BSA 01. Grit size 80 menghasilkan percikan paling pendek yaitu BSA $02440 \mathrm{~mm}$ seperti tercantum dalam Tabel 2. Semakin banyaknya kandungan $0,54 \% \mathrm{C}$ pada material maka panjang spark yang terbentuk semakin pendek bisa dilihat pada grafik Gambar 3.

Tabel 2. Perbandingan jenis material degan Panjang spark

\begin{tabular}{ccccc}
\hline \multirow{2}{*}{ Batu gerinda } & \multicolumn{4}{c}{ Material baja scrap $(\mathbf{m m})$} \\
\cline { 2 - 5 } & BSA 01 & BSA 02 & BSI 01 & BSI 02 \\
\hline GC 36 & 1.171 & 738 & 1.137 & 1.000 \\
GC 60 & 1.020 & 525 & 784 & 661 \\
GC 80 & 746 & 440 & 652 & 612 \\
\hline
\end{tabular}




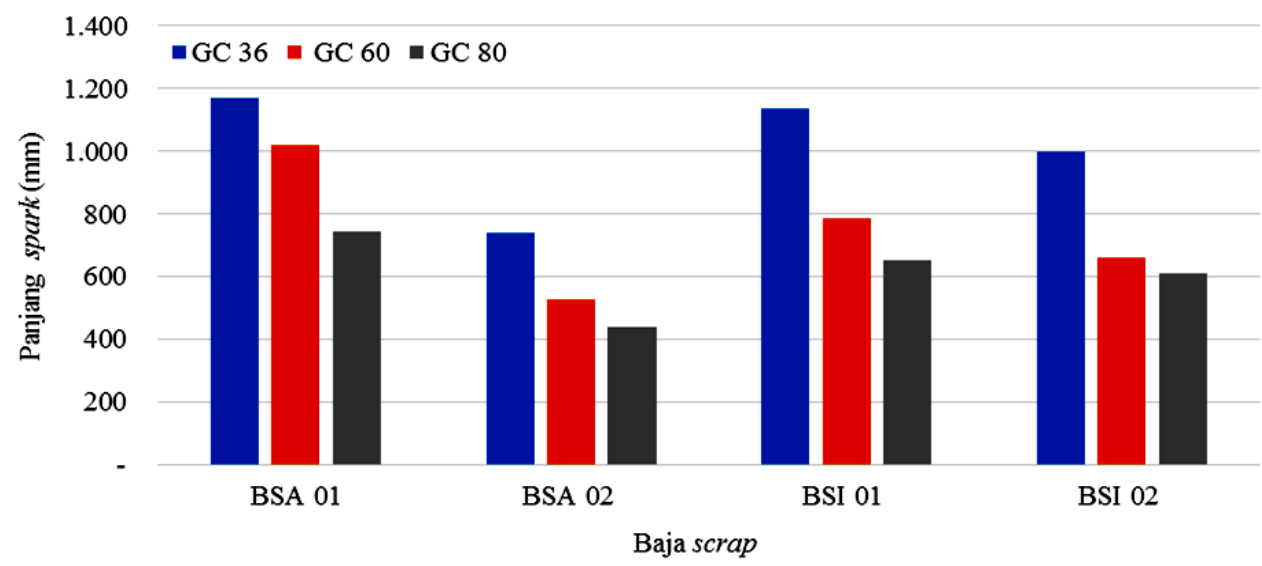

Gambar 3. Hubungan antara grafik panjang spark dengan panjang spark.

Batu gerinda dengan grit size 36 BSA 02 mempunyai sudut paling besar yaitu $42^{\circ}$ dan sudut paling kecil grit size 80 BSA 02 sebesar $18^{\circ}$ tercantum dalam Tabel 3. Tingginya kandungan 0,54\%C yang terdapat pada material baja berpengaruh terhadap bentuk karakterisasi sudut spark semakin meningkatnya kandungan C maka sudut spark lebar bisa dilihat pada grafik Gambar 4.

Tabel 3. Perbandingan jenis material dengan sudut spark

\begin{tabular}{ccccc} 
Batu gerinda & & \multicolumn{2}{c}{ Material baja scrap $\left(^{\circ}\right)$} \\
GC 36 & BSA 01 & BSA 02 & BSI & BSI 02 \\
GC 60 & 16 & 42 & 20 & 25 \\
GC 80 & 21 & 39 & 23 & 28 \\
& 22 & 18 & 24 & 30
\end{tabular}

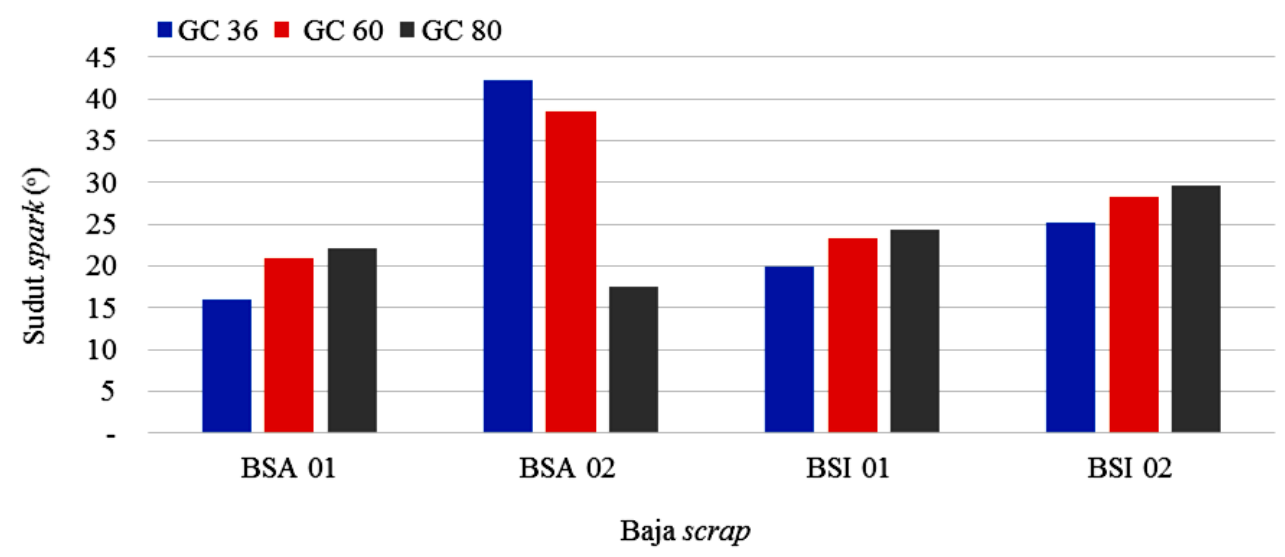

Gambar 4. Hubungan antara grafik baja scrap dengan sudut spark

Tabel 4 menampilkan sudut kontak spark dengan jenis material baja scrap. Batu gerinda dengan grit size 36 mempunyai sudut paling besar adalah $20^{\circ}$ untuk tipe material BSA 01 dan sudut paling kecil untuk batu gerinda grit size $8010^{\circ}$ dengan tipe material BSA 02 . Rendahnya kandungan $0,20 \% \mathrm{C}$ pada material BSI 02 berpengaruh terhadap bentuk karakterisasi sudut kontak spark yaitu semakin rendah kandungan $\mathrm{C}$ maka sudut kontak yang terbentuk semakin kecil dapat dilihat pada grafik Gambar 5. 
Muhamad Sukis dkk /Jurnal Rekayasa Mesin

p-ISSN: 1411-6863, e-ISSN: 2540-7678

Vol.16|No.2|157-164|Agustus|2021

Tabel 4. Perbandingan jenis material dengan sudut kontak spark

\begin{tabular}{ccccc}
\hline \multirow{2}{*}{ Batu gerinda } & & \multicolumn{2}{c}{ Material baja scrap $(\mathbf{0})$} & \\
& BSA 01 & BSA 02 & BSI 01 & BSI 02 \\
GS 36 & 20 & 13 & 19 & 19 \\
GS 60 & 22 & 18 & 24 & 22 \\
GS 80 & 21 & 10 & 19 & 21 \\
\hline
\end{tabular}

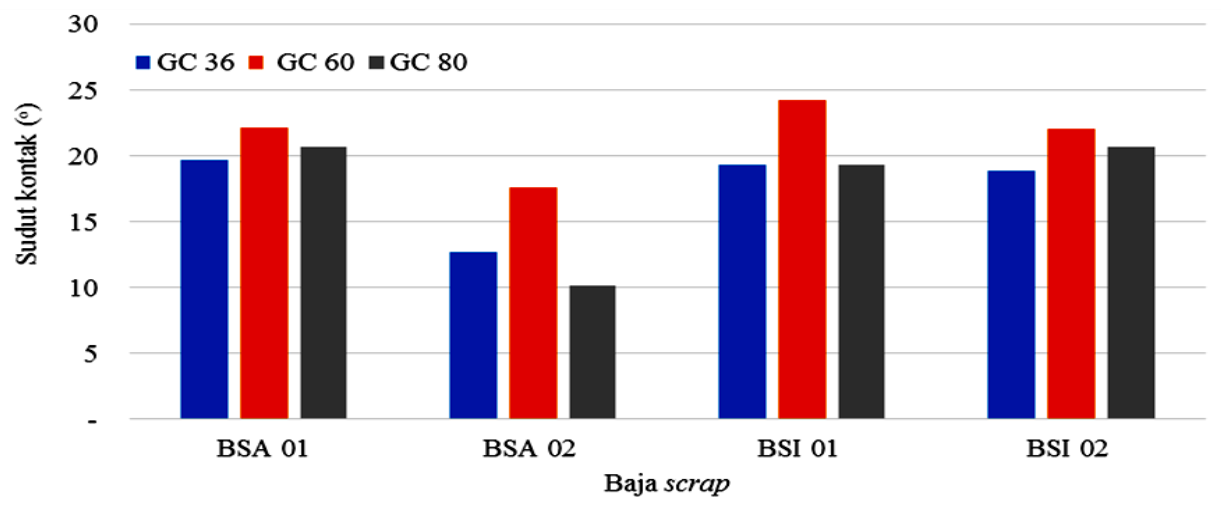

Gambar 5. Hubungan antara grafik baja scrap dengan sudut kontak spark.

Nugroho [6] melakukan penelitian berbagai baja komersil menghasilkan kesimpulan yang relevan dengan penelitian yang dilakukan yaitu semakin tinggi kandungan karbon pada baja maka burst yang terbentuk semakin pekat. Spark dipengaruhi oleh unsur - unsur yang terkandung dalam material tersebut, yang paling dominan bepengaruh terhadap hasil spark dan volume burst yaitu unsur karbon. bahwa semakin tinggi kadar karbon pada material maka volume burst yang terbentuk semakin banyak, dan semakin rendah kandungan karbon pada material maka volume busrt yang tebentuk semakin sedikit [10].

Karakterisasi spark test dari empat spesimen dengan batu gerinda grit 36 dapat dilihat di Gambar 6. Semakin rendahnya kandungan karbon pada material maka panjang spark yang terbentuk semakin panjang dan sudut spark yang terbentuk semakin kecil. Volume spark yang terbentuk pada Gambar 6.b lebih padat karena termasuk baja karbon menengah.

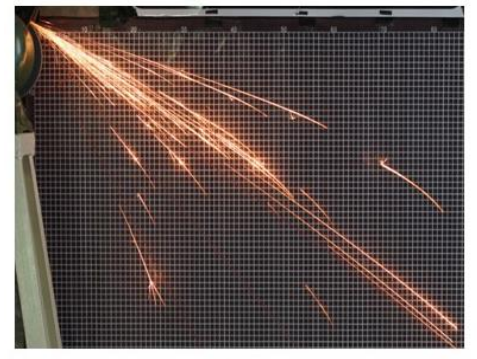

a.

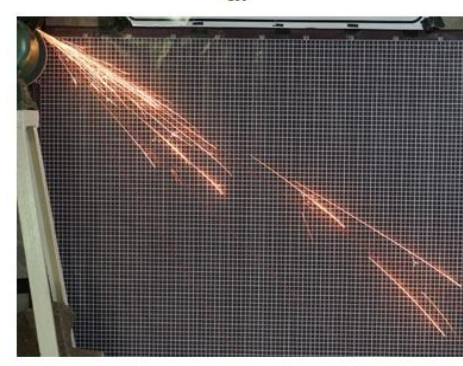

c.

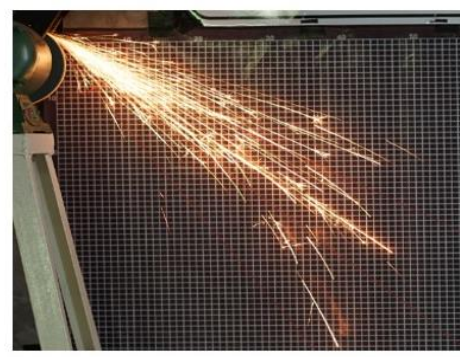

b.

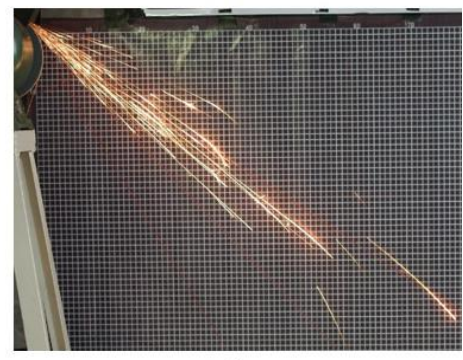

d.

Gambar 6. Karakterisasi spark batu gerinda grit size 36 (a.) BSA 01 (b.) BSA 02 (c.) BS1 01 dan (d.) BSI 02 
Muhamad Sukis dkk /Jurnal Rekayasa Mesin

p-ISSN: 1411-6863, e-ISSN: 2540-7678

Vol.16|No.2|157-164|Agustus|2021

Karakterisasi spark test dari empat spesimen dengan batu gerinda grit 60 dapat dilihat di Gambar 7. Semakin rendahnya kandungan karbon pada material maka panjang spark yang terbentuk semakin panjang dan sudut spark yang terbentuk semakin kecil. Volume spark yang terbentuk pada Gambar 7.b lebih padat karena termasuk baja karbon menengah. Karakterisasi spark cenderung sama dengan grit size 36 dan untuk karakterisai panjang spark pendek.

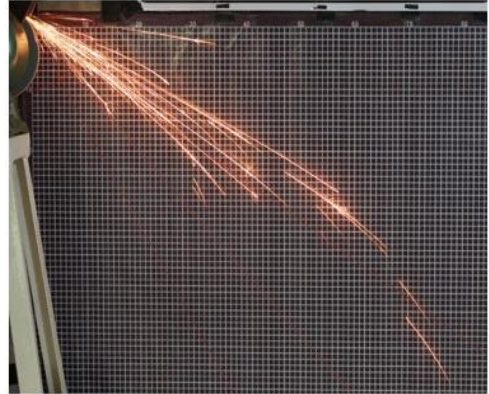

a.

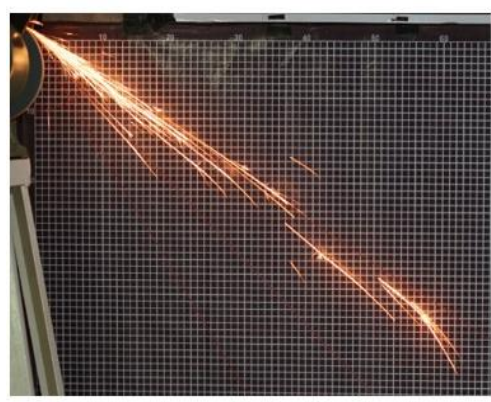

c.

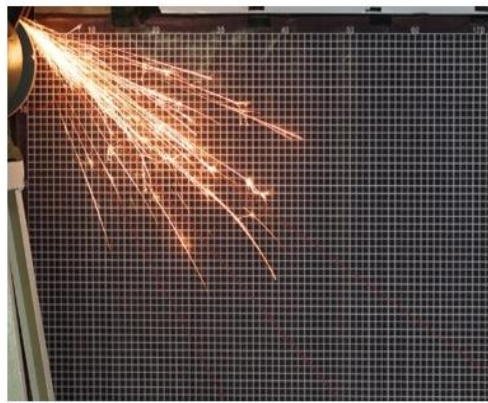

b.

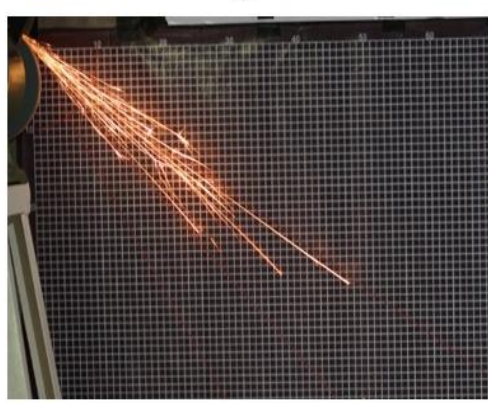

d.

a. Gambar 7. Karakterisasi spark batu gerinda grit size 60 (a.) BSA 01 (b.) BSA 02 (c.) BS1 01 dan (d.) BSI

Karakterisasi spark test dari empat spesimen dengan batu gerinda grit 80 dapat dilihat di Gambar 8. Semakin rendahnya kandungan karbon pada material maka panjang spark yang terbentuk semakin panjang dan sudut spark yang terbentuk semakin kecil. Volume spark yang terbentuk pada Gambar 8.b lebih padat dan sudut sparknya lebar karena termasuk baja karbon menengah.

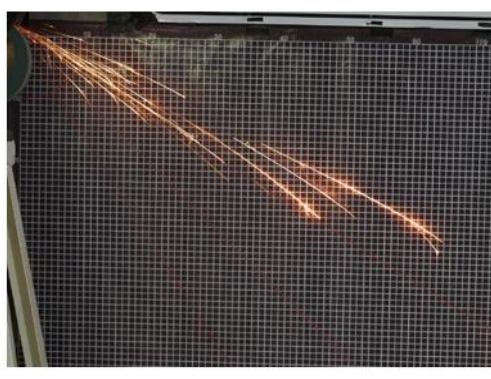

a.

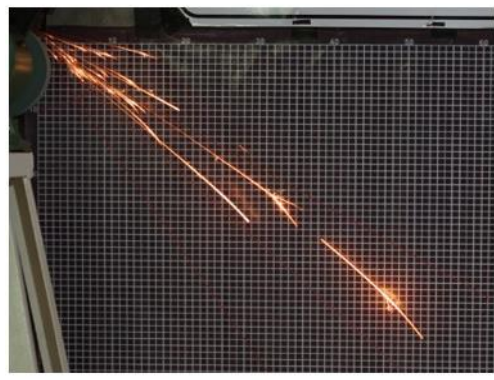

c.

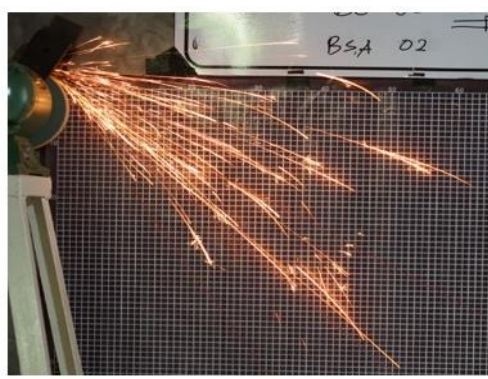

b.

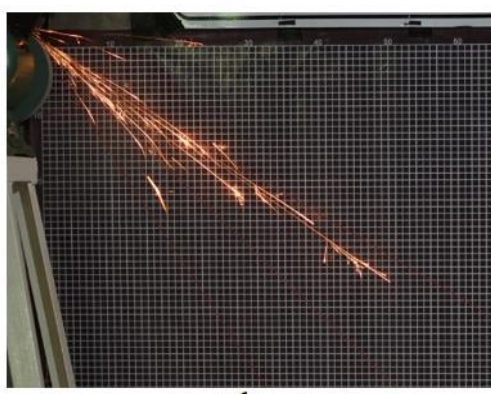

d.

a. Gambar 8. Karakterisasi spark batu gerinda grit size 80 (a.) BSA 01 (b.) BSA 02 (c.) BS1 01 dan (d.) BSI 
Muhamad Sukis dkk /Jurnal Rekayasa Mesin

p-ISSN: 1411-6863, e-ISSN: 2540-7678

Vol.16|No.2|157-164|Agustus|2021

\section{Kesimpulan}

Dari hasil yang telah dibahas diatas maka menyimpulkan bahwa, bentuk karakterisasi spark dan banyaknya volume stream dipengaruhi oleh kandungan komposisi kimia pada baja dan grit batu gerinda, terutama kandungan karbon (C) dimana sangat mempengaruhi bentuk karakterisasi spark. Semakin tinggi kandungan karbon (C) maka semakin lebar sudut spark terbentuk, selain itu panjang spark yang terbentuk akan semakin pendek dan sudut kontak semakin kecil. Tetapi menurunya kandungan karbon (C) pada material baja scrap maka panjang spark yang terbentuk semakin panjang, sudutnya semakin kecil dan sudut kontaknya bertambah lebar. Semakin tingginya kandungan karbon (C) pada baja maka volume burst yang terbentuk semakin meningkat.

\section{Daftar Pustaka}

[1] Deng, K., Pan, D., Li, X., Yin, F. Spark Testing to Measure Carbon Content in Carbon Steels Based on Fractal Box Counting. Meas J Int Meas Confed 2018;133:77-80. https://doi.org/10.1016/j.measurement.2018.10.004.

[2] Goodey, D., Brink, J,. Material Determination Using a Thermal Imaging Camera. World Trans Eng Technol Educ 2015;13:p. 296-301.

[3] Saifuddin, Zulkifli, Arkadius, M,. Pelatihan Pengujian Spark Test Untuk Pengarajin Pandai Besi Tradisional. Proceeding Semin Nas Politek Negeri Lhokseumawe; 2017. (1). p 450-2.

[4] Rawani, K.H,, Painjane, S. V., Salunkhe, A.P., Sanket, S. Patil, PSSD., Prof,P.M.Deshpande,. Experimental Analysis \& Determination of Various Plain Carbon Steels By Using Spark Testing. Int J Res Publ Eng Technol [IJRPET]. 2017; 3: p. 123-8.

[5] Dalke, T., Brink, J., Weller, M,. Material Determination Using Spark Observation. Glob J Eng Educ. 2013; 15: p. $165-70$.

[6] Nugroho, W.I,. Karakterisasi Bentuk, Dimensi Geram, Dan Kekasaran Permukaan Proses Gerinda Silinder Putaran Spindle Rendah Pada Berbagai Baja Komersial. Indonesia: Universitas Diponegoro. 2017; p.13-14, n.d.

[7] W,D. Riley., B, W. Dunning., Jr, DMS,. Spectral Characteristics of Grinding Sparks Used for Identification of Scrap Metals. Bur Mines Rep Investig. 1985; 46: p. 269-75.

[8] Guillen, A., Goh, F., Andre, J., Barral, A., Brochet, C., Louis, Q., et al. From The Microstructure Of Steels to The Explosion of Sparks. 2019; 2: p. 2-7.

[9] Buzzard, R.W,. The Utility Of The Spark Test As Applied To Commercial Steels. Part Bur Stand J Res. 1933; II: p. 4-6.

[10] Nakata, T, Development of Automated Spark Testing Technique by Image Processing to Measure Carbon Content in Steel Materials. IFAC Proc. 2012; 45: p. 118-9.

[11] John, Edgar. K,. Redacted for privacy Redacted for privacy Redactéd for privacy. 1959.

[12] Li, C., Yuan, Y., Amyotte, P., Xiao, M., Zheng, W,. Bu, Y., et al. Friction spark generation and incendivity of several metal alloys. J Loss Prev Process Ind 2021;70:104406. https://doi.org/10.1016/j.jlp.2021.104406.

[13] William, E. B,. Bryson Heat Treatment. First edit. Hanser Publications, Cincinnati; 2015: p.194; n.d.

[14] Rosenfeld, A,. Face Recognition: A Literature Survey Face Recognition: A Literature Survey 2003. https://doi.org/10.1145/954339.954342.

[15] Iskandar, M.A.. Analisis Sifat Fisis Dan Mekanis Tooth Bucket Excavator Sebelum Dan Sesudah Proses Heat Treatmen. Naskah Publ Tugas Akhir; 2013. P. 13-5. 